\title{
Pre-dispersal seed predation and abortion in species of Callisthene and Qualea (Vochysiaceae) in a Neotropical savanna
}

\author{
Luciana Nascimento Custódio $^{1}$, Renata Carmo-Oliveira ${ }^{1}$, Clesnan Mendes-Rodrigues ${ }^{1}$ and Paulo Eugênio Oliveira ${ }^{1,2}$
}

Received: 12 March, 2013. Accepted: 20 December, 2013

\begin{abstract}
The ability of plants to generate fertile offspring is influenced by morpho-physiological and ecological factors. Hence, reproductive success is directly linked to factors affecting quantity and quality of their progeny. In the Cerrado (savanna) of Brazil, the Vochysiaceae is a widely distributed and ecologically important family. Factors affecting pre-dispersal seed predation and abortion were studied for populations of Callisthene fasciculata, C. major, Qualea multiflora and Q. parviflora. To characterize differences between genera, as well as among species, study areas, and individuals, we quantified pre-dispersal seed predation and abortion. Differences of seed abortion among the species were related to intrinsic reproductive features and not to area or other factors. In contrast, seed predation varied not only among species but also among areas and among individuals. Only C. fasciculata showed no seed predation. In Qualea species, insect predators were found inside the seeds; whereas predators of Callisthene species were outside seeds. In both genera, seed abortion correlated negatively with area size, as did pre-dispersal seed predation, which suggest seed abortion may be a counter-measure to avoid predation. Although seed abortion and predation reduced the progenies of the studied species, seed production did not differ from other Cerrado species.
\end{abstract}

Key words: Seed set, abortion, predation, beetles, Neotropics, savanna, Cerrado

\section{Introduction}

The ability of plants to generate fit, fertile offspring is influenced by intrinsic physiological processes, as well as by external biological and physical factors (Crawley 2000). A common phenomenon in the reproductive process of angiosperms is abortion (of the ovule or seed), which can affect the production of fruits and viable seeds (Wiens 1984; Kärkkäinen et al. 1999; Latta 2005; Porcher \& Lande 2005). Many species allocate a great quantity of resources to flowers. Although most of those flowers will fail to develop into fruits, they might represent spare parts to be called upon in case of environmental stress, predation or disease. In addition, more flowers translates to increased pollen availability, attracting more pollinators and increasing pollen flow, thus allowing post-pollination gametophytic selection and selective abortion, which seems to improve fruit and seed quality (Janzen 1978; Stephenson 1981; Melser \& Klinkhamer 2001).

Seed abortion is particularly common among selfincompatible species and woody perennials in particular, affecting more than $50 \%$ of the number of all ovules produced (Wiens 1984). Because mother plants have limited resources for production, protection and seed dispersal, there are obligatory trade-offs among the size, quality and quantity of the seeds they produce (Haig \& Westoby 1988). Therefore, seed abortion might result from parental resource allocation and competition among siblings (Bawa et al. 1989; Uma Shaanker \& Ganeshaiah 1997).

In addition to resource limitation and environmental stress, seed abortion and loss of mature seeds can be caused by pollen limitation and inbreeding (Wiens et al. 1987); breeding system incompatibility (Dhar et al. 2006); by genetic load (Wiens et al. 1987; Bawa et al. 1989; Porcher \& Lande 2005); and by abnormalities during ovule ontogeny (Palser et al. 1990; Sedgley \& Granger 1996). Therefore, seed abortion is the main mechanism of post-zygotic selection in plants, allowing resource allocation to be optimized and pre-dispersal seed predation to be avoided (Gribel \& Gibbs 2002; Ward et al. 2005; Chacoff et al. 2008; Ghazoul \& Satake 2009).

Seed production and survival are affected not only by brood selection, competition, and environmental factors but also by seed predators. Protein and nutrient content are usually higher in seeds than in vegetative tissues, and the seeds are, therefore, targeted by predators (Janzen 1971b; Mattson 1980; Willson 1983). There are two basic types of seed predation: pre-dispersal predation, which occurs

\footnotetext{
${ }^{1}$ Universidade Federal de Uberlândia, Instituto de Biologia, Campus Umuarama, Uberlândia, MG, Brasil

${ }^{2}$ Author for correspondence: poliveira@ufu.br
} 
while the seed is still attached to the mother plant; and post-dispersal predation, which occurs after separation from the mother plant but before the germination process begins (Janzen 1971b; 1978). The primary groups of seed predators include the larval instars and immature stages of Diptera, Coleoptera, Hymenoptera and Lepidoptera (Janzen 1970, 1971a; Ehrlén 1996; Crawley 2000; Spironello et al. 2004; Tuda et al. 2009). Pre-dispersal seed predation, the rate of which can be higher than $80 \%$ (in natural and cultivated areas alike), exerts enormous pressure on plant reproduction (Andersen 1988; Janzen 1970, 1971a; Zhang et al. 1997). In the typical scenario, adult female predators deposit their eggs inside developing ovaries or individual ovules; as the larvae and immature stages develop, they consume parts of the endosperm and embryo before the fruit or seed can mature (Ehrlén 1996; Barreto et al. 1999).

Seed abortion and predation are both considered determinants of the size and reproductive ecology of plant populations (Janzen 1971a, 1971b; Bradford \& Smith 1977; Garcia et al. 2000; Leimu et al. 2002; Ghazoul \& Satake 2009). Studies comparing populations in terms of the occurrence of abortion and predation can further understanding of the ecological consequences to plant reproduction and persistence (Bradford \& Smith 1977; Ehrlén 1996; Pizo 1997; Crawley 2000; García et al. 2000, 2001; Steffan-Dewenter et al. 2001; Leimu et al. 2002; Baldissera \& Ganade 2005; Marino et al. 2005; Figueiredo et al. 2008). In the Cerrado of Brazil, one of the most well-represented and characteristic families of woody plants is the Vochysiaceae, some species of which are among the most common and widespread in the Biome (Haridassan \& Araújo 1988; Ratter et al. 1996; Appolinário \& Schiavini 2002; Lopes et al. 2011). Vochysiaceae species are mostly self-incompatible, having been reported to feature fruit and seed abortion (Carmo-Oliveira 1998; Oliveira 1998). Seeds are wind-dispersed and recalcitrant in terms of germination, quickly losing their viability in storage (Boesewinkel \& Venturelli 1987; Farnsworth 2000). Seed predation and its consequences for reproductive outcomes have not been studied in detail. In this context, the objective of this study was to quantify and compare the frequency of pre-dispersal seed predation and abortion in different populations of Callisthene and Qualea (Vochysiaceae) species within the Cerrado Biome, evaluating their consequences for the reproductive ability of the species. We hypothesized that these processes would be interrelated and would play a role in plant strategies to cope with predation.

\section{Materials and methods}

\section{Species studied}

The occurrence of pre-dispersal seed predation and abortion was studied for populations of Callisthene fasciculata Mart., Callisthene major Mart., Qualea multiflora Mart. and Qualea parviflora Mart. A brief description of the main morphological and reproductive features of the plants is provided below.

Trees of the species Callisthene fasciculata are 5-8 m tall and occur on the shallow Entisols common to rocky basalt outcrops. These soils are relatively rich in nutrients and are associated with fragments of dry deciduous forest within the Cerrado Biome. The trees bloom for a short period in September and October when they are leafless, simultaneously dispersing the seeds from the previous year. The flowers are self-incompatible and bee-pollinated. The ovary is superior and trilocular, with two fully developed ovules per locus The fruits are loculicidal capsules that open almost one year after flowering (Santos 1997).

Callisthene major is a tree that occurs in the areas of cerradão (woodland savanna) and semideciduous forests of the Cerrado Biome. Leaf flush and flowering occur between August and September. Flowers are also self-incompatible and pollinated by small social bees such as Apis mellifera. As in C. fasciculata, the ovary is superior and trilocular, with two fully developed ovules per locus. Fruits take nearly a year to mature, and seeds are wind-dispersed (CarmoOliveira 1998; Oliveira 1998).

Qualea multiflora is a shrub or small tree up to $6 \mathrm{~m}$ tall, occurring in open areas of cerrado sensu stricto in central Brazil. Flowering begins in October, just after the seed dispersal and leaf flushing in September, and continues until February. The flowers present a single stamen and superior ovary with up to six fully formed ovules per locus. It is self-incompatible and pollinated by large Xylocopa and Centris bees. Fruits are loculicidal capsules with winged seeds (Oliveira 1998).

Qualea parviflora is a species of tree that grows up to 8 $\mathrm{m}$ in height and is quite common in open areas of cerrado sensu stricto. Leaves are verticillate with extrafloral nectaries at the base of their petioles. The axillary inflorescences are produced from September to December. The flowers, which are self-incompatible and bee-pollinated, are smaller than are those of Q. multiflora, featuring a single lilac petal with a white nectar guide and a spurred calyx. Like those of Q. multiflora, the flowers of Q. parviflora present a single stamen and a superior trilocular ovary with six ovules per locus. The loculicidal capsule typically releases only two seeds per locus, one year after flowering (Oliveira 1998).

\section{Study areas}

For all four of the species studied, fruit were collected in seven different protected areas: six in the state of Minas Gerais-the Clube Caça e Pesca Itororó de Uberlândia (CCPIU, Itororó Hunting and Fishing Club of Uberlândia); the natural areas surrounding the Capim Branco II hydroelectric dam (CBII); Panga Ecological Station (PES); Glória Experimental Farm (GEF); Limoeiro Farm (LF); and Parque Nacional da Serra da Canastra (PARNASC, Serra da Canastra National Park) — and one in the state of Goiás_Parque Estadual da Serra de Caldas Novas (PESCAN, Serra de Caldas Novas State Park). 
The CCPIU ( $\left.18^{\circ} 59^{\prime} \mathrm{S} ; 48^{\circ} 18^{\prime} \mathrm{W}\right)$, located $8 \mathrm{~km}$ southeast of the city of Uberlândia, comprises 127 ha of private ecological reserve dominated by cerrado sensu stricto and palm swamps (Appolinário \& Schiavini 2002). Mature fruits of Qualea multiflora and Q. parviflora were collected from alongside the road that runs through the area.

Sampling at the CBII $\left(18^{\circ} 35^{\prime} \mathrm{S} ; 48^{\circ} 24^{\prime} \mathrm{W}\right)$ was done at $\mathrm{km}$ 131 of state road MG 223 in a fragment of semideciduous forest surrounded by coffee plantations and pastures. Fruits of Callisthene fasciculata were collected from trees within the forest, whereas Qualea multiflora fruits were obtained from isolated individuals at the forest edge.

The PES ( $19^{\circ} 10^{\prime} \mathrm{S} ; 48^{\circ} 23^{\prime} \mathrm{W}$ ) comprises 409.5 ha, located $30 \mathrm{~km}$ southeast of Uberlândia. It is one of the few protected areas in the "Triângulo Mineiro" (Minas Triangle) region (Cardoso et al. 2009) and features various vegetation formations characteristic of the Cerrado Biome (Schiavini \& Araújo 1989). Fruits of Qualea multiflora and Q. parviflora were collected in an area of cerrado sensu stricto.

The GEF ( $18^{\circ} 56^{\prime}$ S; $48^{\circ} 12^{\prime} \mathrm{W}$ ) comprises an area of 685 ha within the city of Uberlândia. Although some of the GEF land is used for agricultural and cattle ranching experiments, the area also includes preserved forest fragments (Haridasan \& Araújo 1988), from which we collected fruits and seeds of Callisthene major.

The LF ( $\left.18^{\circ} 33^{\prime} \mathrm{S} ; 48^{\circ} 28^{\prime} \mathrm{W}\right)$ is a private farm, located approximately $35 \mathrm{~km}$ southeast from Uberlândia, on state road MG 223. It presents an area of $\approx 3$ ha, comprising a fragment of cerrado and a deciduous dry forest, both on a basalt outcrop (Santos 1997), from which we collected seeds of Callisthene fasciculata and Qualea parviflora.

The PARNASC $\left(20^{\circ} 10^{\prime} \mathrm{S} ; 46^{\circ} 33^{\prime} \mathrm{W}\right)$ is approximately 200 $\mathrm{km}$ east of Uberlândia, between the cities of Delfinópolis, São Roque de Minas and Sacramento. It comprises an area of 71,525 ha and features a great variety of vegetation formations, with high levels of endemism (Romero \& Nakajima 1999). We collected fruits of Callisthene major near Rolinhos Waterfall, which is in the northeastern sector of the park.

The PESCAN ( $17^{\circ} 46^{\prime} \mathrm{S} ; 48^{\circ} 40^{\prime} \mathrm{W}$ ) is a area of 12,500 ha, located on a plateau (at $1043 \mathrm{~m}$ a.s.l.) between the cities of Caldas Novas and Rio Quente, in the state of Goiás (Almeda \& Sarmento 1998), approximately $200 \mathrm{~km}$ northwest of Uberlândia. Although the plateau presents a great variety of vegetation formations characteristic of the Cerrado Biome, it is dominated by cerrado sensu stricto (Lopes et al. 2011), from which we collected fruits of Qualea multiflora and Q. parviflora.

Voucher specimens were deposited in the Herbarium of the Federal University of Uberlândia (code, HUFU), in Uberlândia: Callisthene fasciculata (HUFU 55467-CBII; HUFU 55466-LF). Callisthene major (HUFU 45808-GEF; HUFU 55470-PARNASC). Qualea multiflora (HUFU 44918-CCPIU; HUFU 55469-CBII; HUFU 55468-PESCAN) and Qualea parviflora (HUFU 44919-CCPIU; HUFU 55464-LF; HUFU 55465-PESCAN).

\section{Seed abortion and predation sampling}

Fruits were collected between July and August of 2009, when all fruits were completely developed but before final maturation and dispersal. We collected fruits from at least five individuals per species in each of the seven populations evaluated. Due to the large volume of fruits collected, some were frozen for later analysis. We did not use any randomization procedure during collection, rather attempting to collect a similar number of fruits from each individual, although from different branches.

From each fruit, the seeds were removed and analyzed for the presence of embryos. The seeds containing embryos were stored in $70 \%$ ethanol. As previously mentioned, Qualea and Callisthene species present three pairs of ovules, resulting in a maximum of six seeds per fruit. Hence, the abortion rate was the number of missing viable seeds devided by six. This abortion rate was calculated for each population and individual using each fruit as a sampling unit.

The presence of endophagous insects or evidence of pre-dispersal seed predation was evaluated during fruit and seed abortion analyses. Seeds were dissected under stereomicroscopy in order to detect endophagous insect eggs, larvae or adults. The predation rate was calculated for embryo-containing seeds. Insect specimens were fixed in $70 \%$ ethanol for later identification.

\section{Statistical analysis}

To compare the frequency (rate) of aborted and predated seeds among areas and among individuals within each area, we used a generalized linear model with binary logistic distribution (Crawley 2007). The same procedure was used in comparing abortion and predation rates among Callisthene fasciculata, C. major, Qualea multiflora and Q. parviflora, as well as between the two genera. All analyses were conducted using the GLzM module of the Statistical Package for the Social Sciences, version 17.0 (SPSS, Inc., Chicago, IL, USA) with Type III test. To correlate abortion and predation rates for the populations of the two Qualea species, we calculated Spearman's correlation coefficient $\left(r_{S}\right)$ using the SYSTAT ${ }^{\circ}$ program, version 10.2 (Systat Software Inc., San Jose, CA, USA).

\section{Results}

\section{Seed morphology and abortion}

The proportion of aborted seeds per fruit greatly varied among individuals and populations but was markedly different between the two genera. In Callisthene fasciculata, embryo-less (aborted) seeds were thinner and darker than were embryo-containing seeds, although some aborted seeds showed a normal wing. We also found marked differences in C. major, in which embryo-containing seeds were larger and 
had a fully developed wing. However, in both Qualea species, the size of aborted seeds did not differ greatly from that of viable seeds, and both showed wing development. The primary difference was the absence of the embryo itself, which was replaced by a resinous mass, although the seed integuments and other tissues developed as in the viable seeds.

\section{Seed abortion rate}

In all of the populations analyzed, we observed seed abortion-i.e., the development of seeds without embryos (Fig. 1). Species of Callisthene presented higher abortion rates than did those of Qualea. Abortion rates differed among areas and among species (Tab. 1), ranging from 22.3\% in Qualea multiflora to $68.2 \%$ in Callisthene fasciculata and differing markedly between areas for the latter (Fig. 1). Callisthene major also presented high abortion rates (Fig. 1), although with no significant difference between areas (Tab. 1). Abortion rates for Q. multiflora, which were the lowest (only $20 \%$ ), differed among areas and among individuals within areas (Fig. 1 and Tab. 1), whereas Q. parviflora presented abortion rates of $31.2-48.2 \%$ and also showed significant differences among areas and among individuals within areas (Fig. 1 and Tab. 1). Among the areas evaluated, the abortion rate was lowest in the LF.

For Callisthene fasciculata, half of the analyzed fruits (51.3\%) presented five of the six possible seeds aborted in the CBII (Fig. 2), compared with only four of the six in the LF. For C. major, the abortion rates were similar among areas (Fig. 2 ), most fruits containing only three or four aborted seeds (74.70\% in the PARNASC and $82.70 \%$ in the GEF). For the genus Callisthene as a whole, there were very few fruits with no aborted seeds (five for C. fasciculata and one for C. major). Qualea multiflora presented a larger number of fruits with few or no aborted seeds (Fig. 2), 21.5\% of all Q. multiflora fruits presenting no aborted seeds. In Q. parviflora, the number of aborted seeds was higher and varied more widely, without a clear trend among areas and individuals (Fig. 2).

To compare the abortion rates for each species, we took into consideration the differences between individuals and populations. We found that seed abortion differed significantly among the four species studied (Tab. 2). The numbers of aborted seeds were significantly higher among Callisthene species than among Qualea species (Tab. 2), differing between Q. multiflora and Q. parviflora but not between C. fasciculata and C. major.

\section{Pre-dispersal seed predation}

The insect groups found inside fruits and seeds varied among the four tree species evaluated. Different forms of predation were observed for Callisthene and Qualea. Although it was not possible to identify predators to the species level, the general predation behavior was similar among morphospecies in each large group of insects.
We observed no seed predation in the fruits of Callisthene fasciculata. In C. major, predatory insects were found inside the fruits but not within the seeds. In that species, adult Curculionidae (Coleoptera), as depicted in Fig. 3A-C, preyed on seeds by drilling into the integuments in order to access the developed embryos. Thus, all seeds in the fruits of $C$. major were preyed upon by these insects. In contrast, the insects found in both Qualea species were only inside the seeds, causing damage to the embryos in their final developmental stage. Different instars of Buprestidae (Coleoptera) and Hymenoptera were found inside embryo-containing seeds at the cotyledon stage (Fig.3D-F). The presence of immature stages and adults of both groups indicate that these insects complete their development inside the seeds, consuming the embryos and seed content when they are fully developed but before fruit maturation and seed dispersal. The presence of Buprestidae (Coleoptera) was much more common than was that of the Hymenoptera, which were probably parasitoids (Fig. 3G-N).

\section{Pre-dispersal seed predation rate}

As previously mentioned, there was no pre-dispersal seed predation in Callisthene fasciculata in either of the two areas in which it occurred (Fig. 1). There were populations of C. major and Qualea multiflora with and without predation, whereas there was evidence of seed predation in all sampled populations of Q. parviflora (Fig. 1 and Tab. 3). In C. major, predation occurred only in the PARNASC population. In Q. multiflora, predation rates were high only in the PES and PESCAN populations, and pairwise comparisons showed that those two populations differed from each other. All four populations of $Q$. parviflora presented relatively high seed predation rates. For the LF, PESCAN and PES, seed predation rates were $\approx 50 \%$ and did not differ significantly among the three areas, being significantly different only for the CCPIU, where it was lower $(\approx 20 \%)$. Differences in the predation rate among populations were significant only for Q. parviflora (Tab. 4). Seed predation rates varied significantly among areas and individuals within species and genera (Tab. 4). However, unlike what was observed for abortion rates, the differences between genera and species were not significant.

\section{Abortion and pre-dispersal seed predation for sympatric species of Qualea}

Comparing the sympatric Qualea species, we found that the seed abortion rate varied mostly as a function of species, whereas the seed predation rate varied as a function of area and of species. For the seed abortion rate, there was no interaction between the factors area and species (Wald chi-square $\left.\left[\chi^{2}\right]=4.36 ; p=0.113\right)$. The areas sampled for two Qualea species (Fig. 4A) did not show significant differences in terms of the abortion rate $\left(\chi^{2}=2.17 ; p=0.339\right)$, whereas the abortion rate did differ between those two species (Fig. 4B), 


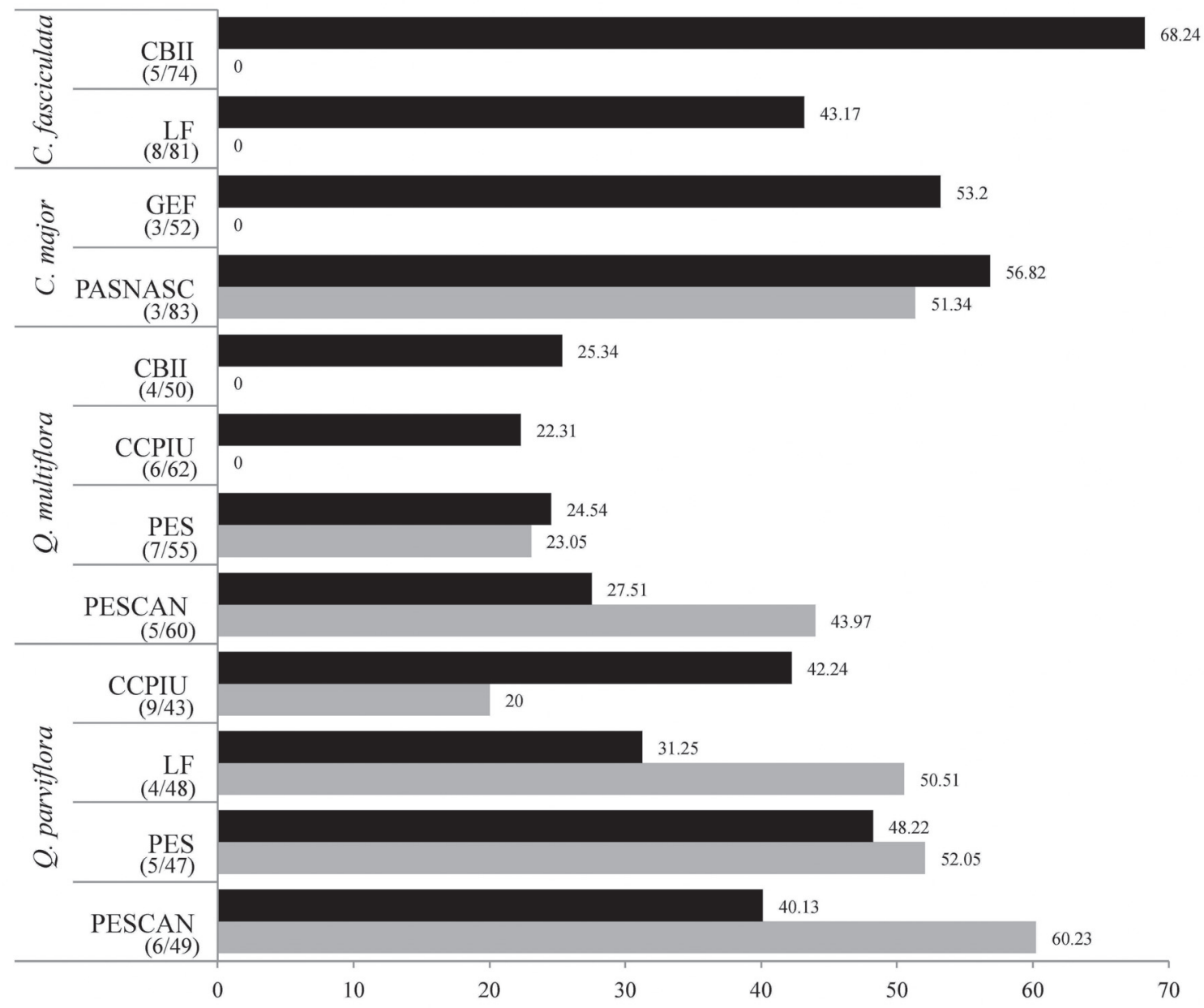

- Frequency of seed abortion $\quad$ Frequency of seed predation

Figure 1. Rate (\%) of seed abortion and seed predation for Callisthene and Qualea species in each studied area.*

CBII - natural areas surrounding the Capim Branco II hydroelectric dam; LF - Limoeiro farm; GEF - Glória Experimental Farm; PES - Panga Ecological Station; PARNASC - Parque Nacional da Serra da Canastra (Serra da Canastra National Park); CCPIU - Clube Caça e Pesca Itororó de Uberlândia (Itororó Hunting and Fishing Club of Uberlândia); and PESCAN - Parque Estadual da Serra de Caldas Novas (Serra de Caldas Novas State Park).

${ }^{*}$ For each species-area pair, the number of individuals/total number of fruits analyzed are shown in parentheses.

Table 1. Differences in seed abortion rate among the Vochysiaceae studied species. Values were derived from generalized linear models, with areas and individuals nested within areas as factors, the abortion rate being the dependent variable.

\begin{tabular}{lcccc}
\hline Species & Factor & $d f$ & $\chi^{2}$ & $p$ \\
\hline \multirow{2}{*}{ Callisthene fasciculata } & Area & 1 & 51.095 & $<0.001$ \\
& Individuals within areas & 11 & 41.993 & $<0.001$ \\
Callisthene major & Areas & 1 & 1.871 & 0.171 \\
& Individuals within areas & 4 & 2.566 & 0.633 \\
Qualea multiflora & Areas & 3 & 408.756 & $<0.001$ \\
& Individuals within areas & 17 & 38.730 & 0.002 \\
Qualea parviflora & Areas & 3 & 1415.069 & $<0.001$ \\
& Individuals within areas & 23 & 89.059 & $<0.001$ \\
\hline
\end{tabular}

$\chi^{2}$ - Wald chi-square test. 
Callisthene fasciculata

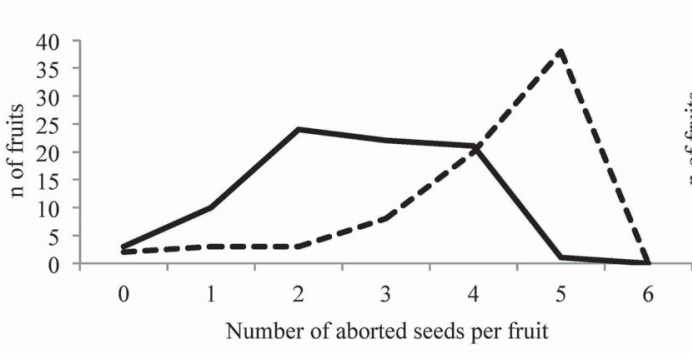

- LF

$---\mathrm{CBI}$
Callisthene major

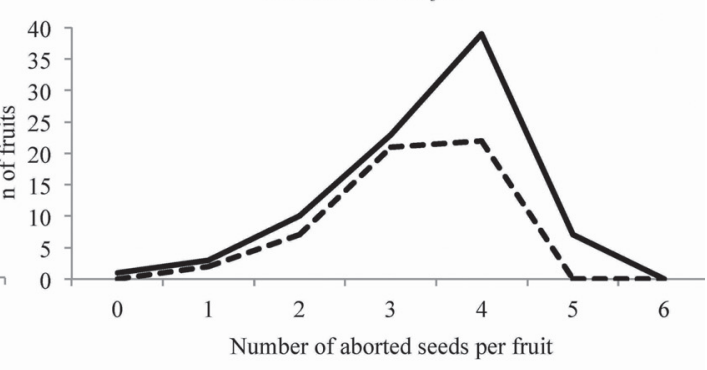

- PARNASC $\quad---$ GEF
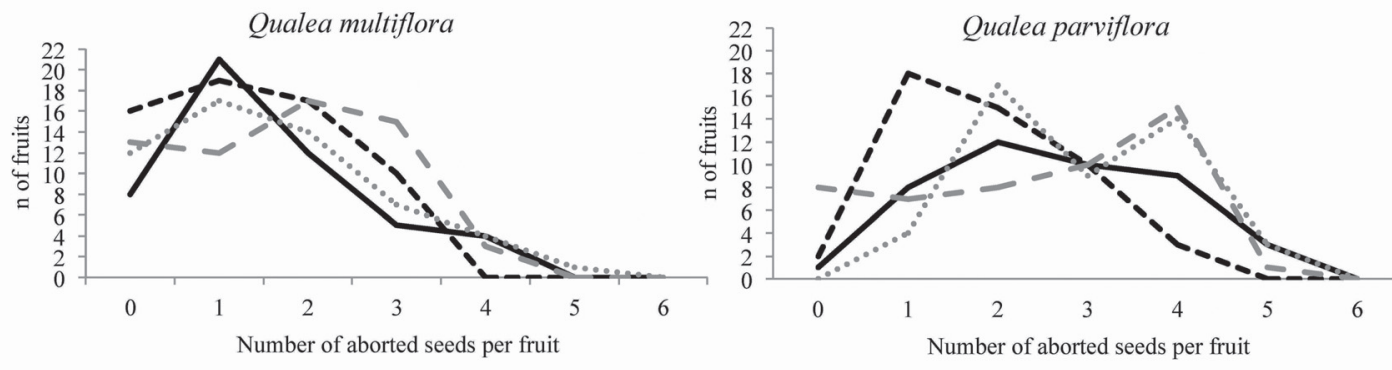

$\begin{array}{ll}-\mathrm{CBII} & --\mathrm{CCPIU} \\ \cdots & -\end{array}$

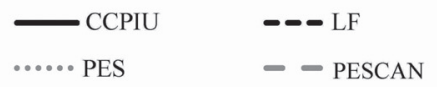

Figure 2. Frequency of fruits as a function of the number of aborted seeds in Callisthene and Qualea species, by area.

CBII - natural areas surrounding the Capim Branco II hydroelectric dam; LF - Limoeiro farm; GEF - Glória Experimental Farm; PES - Panga Ecological Station; PARNASC - Parque Nacional da Serra da Canastra (Serra da Canastra National Park); CCPIU - Clube Caça e Pesca Itororó de Uberlândia (Itororó Hunting and Fishing Club of Uberlândia); PESCAN - Parque Estadual da Serra de Caldas Novas (Serra de Caldas Novas State Park).

Table 2. Seed abortion rate among the four species studied and between the two genera (Callisthene and Qualea). Values were derived from generalized linear models results for each genus, the factors being species nested within genera, areas nested within species and individuals nested within areas.

\begin{tabular}{|c|c|c|c|c|}
\hline Level & Factor & $d f$ & $x^{2}$ & $p$ \\
\hline \multirow{3}{*}{ Species } & Species & 3 & 183.976 & $<0.001$ \\
\hline & Areas (species) & 5 & 64.714 & $<0.001$ \\
\hline & Individuals within areas & 23 & 103.051 & $<0.001$ \\
\hline \multirow{4}{*}{ Genus } & Genus & 1 & 121.657 & $<0.001$ \\
\hline & Species (genera) & 1 & 14.112 & $<0.001$ \\
\hline & Areas (species) & 3 & 49.232 & $<0.001$ \\
\hline & Individuals within areas & 23 & 112.677 & $<0.001$ \\
\hline
\end{tabular}

$\chi^{2}-$ Wald chi-square test.

regardless of the area $\left(\chi^{2}=72.60 ; p<0.001\right)$. These analyses showed that seed abortion seems to be characteristic of the species as a whole, without marked differences among areas or between populations (Fig. 4B).

In the seed predation analysis, we observed a significant influence on predation for the factors area $\left(\chi^{2}=5070.76\right.$; $p<0.01)$ and species $\left(\chi^{2}=5607.21 ; p<0.01\right)$, with a significant interaction between the two factors $\left(\chi^{2}=4.94 ; p=0.026\right)$ For both Qualea species, seed predation rate was higher in the PESCAN than in the PES and CCPIU (Fig. 4C and 4D).

The fruits of Qualea multiflora presented lower rates of seed abortion and predation than did those of Q. parviflora, and there was a positive, albeit weak, correlation between seed abortion and seed predation for some Q. multiflora populations (Tab. 5). For Q. parviflora, the correlation between seed abortion and seed predation was strongest in 

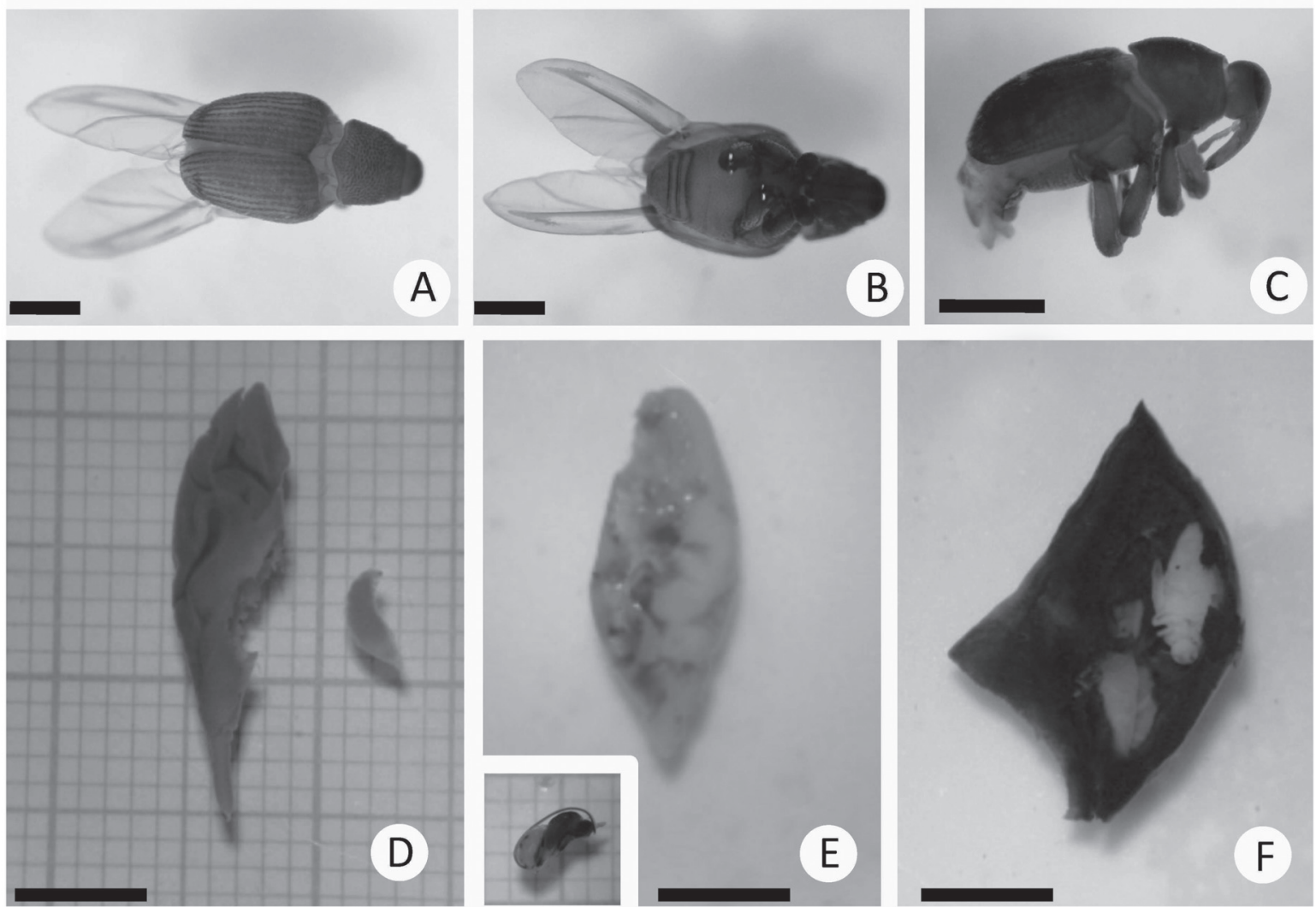

C
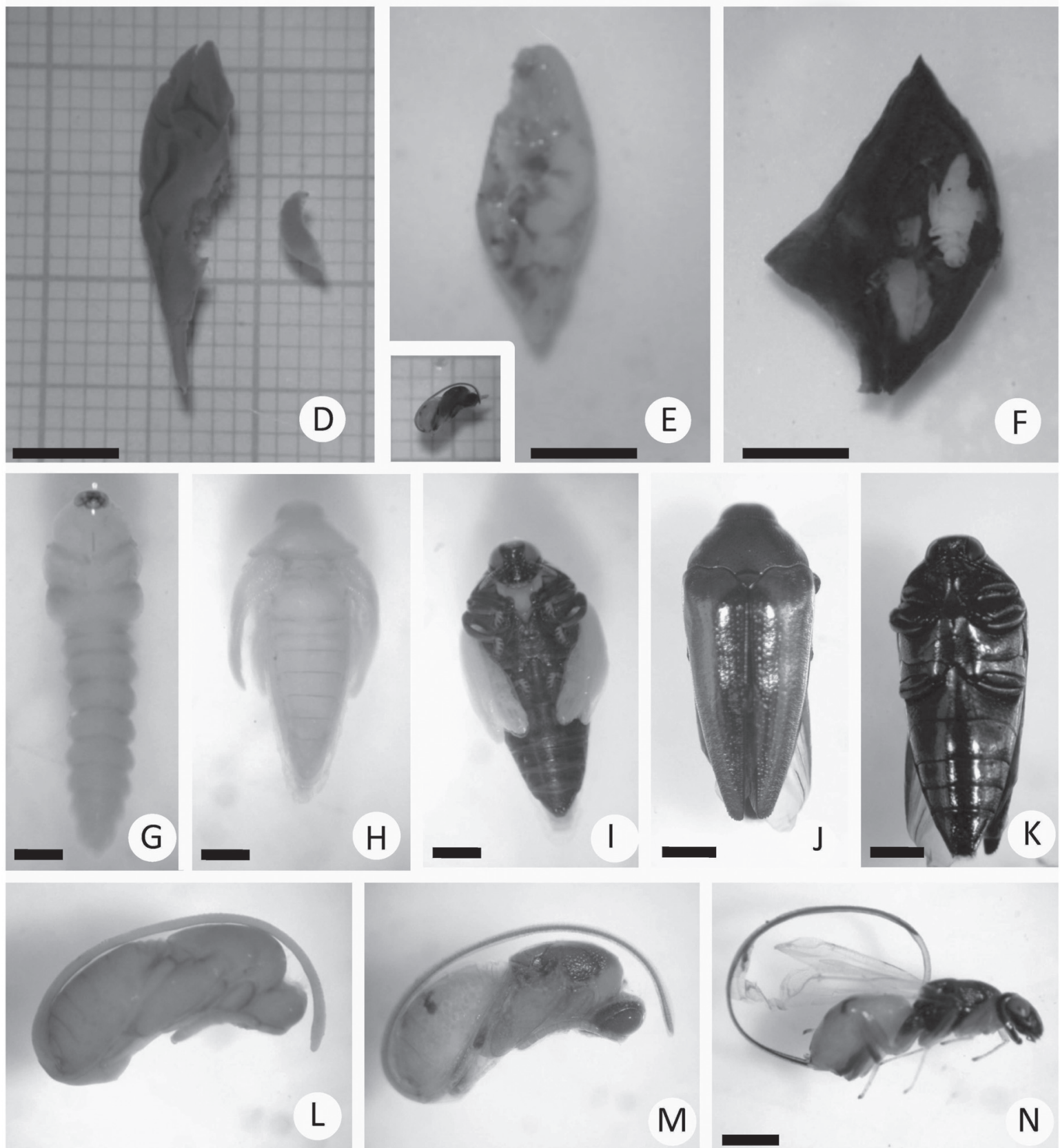

Figure 3. Diversity of insect predators found inside the Vochysiaceae studied seeds. A-C. Specimens of Curculionidae beetles (Coleoptera) removed from Callisthene major fruits collected in Serra de Caldas Novas State Park: A) dorsal view; B) ventral view; C) lateral view showing the rostrum (arrow). D-F. Embryos, seed predators and predated seeds of Qualea multiflora: D) an embryo at the cotyledon stage preyed upon by a larva; E) insect-damaged embryo and detail of an immature stage of Hymenoptera found inside a seed; F) cotyledon-stage embryo and an immature beetle (Coleoptera: Buprestidae). G-N. Specimens of predators and parasitoids found inside seeds of Qualea species: G-K) beetles (Coleoptera: Buprestidae) at different developmental stages; L-N) immature stages and an adult of a parasitoid Hymenoptera with a long ovipositor. Scale bars $=0.50 \mathrm{~cm}(\mathrm{~A}-\mathrm{F})$ and $1 \mathrm{~mm}(\mathrm{G}-\mathrm{N})$. 
Table 3. Pre-dispersal seed predation rates for the Vochysiaceae studied species. Values were derived from generalized linear models for areas and individuals nested within areas as factors, the frequency of seed predation being the dependent variable.

\begin{tabular}{|c|c|c|c|c|}
\hline Species & Factor & df & $\chi^{2}$ & $\mathrm{p}$ \\
\hline \multirow{2}{*}{ Callisthene major } & Areas & 1 & 0.000 & 1.000 \\
\hline & Individuals within areas & 4 & 8.951 & 0.062 \\
\hline \multirow{2}{*}{ Qualea multiflora } & Areas & 3 & 0.000 & 1.000 \\
\hline & Individuals within areas & 17 & 87.297 & $<0.001$ \\
\hline \multirow{2}{*}{ Qualea parviflora } & Areas & 3 & 463.325 & $<0.001$ \\
\hline & Individuals within areas & 18 & 8933.539 & $<0.001$ \\
\hline
\end{tabular}

$\chi^{2}$ - Wald chi-square test.

Table 4. Pre-dispersal seed predation rates for the genera Callisthene and Qualea (Vochysiaceae). Values were derived from generalized linear models for species, with areas nested within species and individuals nested within areas as factors, the frequency of seed predation being the dependent variable.

\begin{tabular}{lcccc}
\hline Level & Factor & $\mathrm{df}$ & $\chi^{2}$ & $\mathrm{p}$ \\
\hline \multirow{3}{*}{ Species } & Species & 3 & 0.000 & 1.000 \\
& Areas (species) & 5 & 50.776 & $<0.001$ \\
& Individuals within areas & 23 & 176.087 & $<0.001$ \\
& Genus & 1 & 0.000 & 1.000 \\
Genus & Species (genera) & 1 & 0.000 & 1.000 \\
& Areas (species) & 3 & 21.683 & $<0.001$ \\
& Individuals within areas & 18 & 99.176 & $<0.001$ \\
\hline
\end{tabular}

$\chi^{2}-$ Wald chi-square statistics.

the PES population $\left(r_{\mathrm{S}}=0.638 ; p<0.05\right)$. These correlations suggest that predation is influenced by the number of viable seeds formed, the predation rate increasing in proportion to the number of viable seeds per fruit.

Qualea multiflora presented a significant correlation between the number of viable seeds and the predation rate only for the CBII, although the predation rate was very low and the correlation was weak $\left(r_{\mathrm{s}}=0.373 ; p<0.05\right)$. Abortion and predation both reduce the rate of development from ovule to seed, which is an indicator of reproductive efficacy (Tab. 6). Reproductive efficacy was highest for Q. multiflora and lowest for Q. parviflora, in which abortion and predation both contributed to reducing the number of ovules that developed into seeds.

\section{Discussion}

\section{Seed abortion}

We observed seed abortion in all species and populations, the seed abortion rate being above $50 \%$ in both of the Callisthene species studied, more than half of the ovule budget being expended during the process. Seed abortion rates of 20-60\% have been described for other plant species (García et al. 2000; Allphin et al. 2002; López-Almansa et al. 2004; Teixeira et al. 2006), corroborating data showing that seed abortion is especially common among self-incompatible trees and perennial trees (Sorensen 1982; Wiens 1984).

In the family Vochysiaceae, the seed abortion rate seems to be related to intrinsic features, given that it did not vary with time. A study carried out in 2007 showed similar abortion rates for Callisthene fasciculata, C. major, Qualea multiflora and Q. parviflora (64\%, 73.7\%, 19.61\% and $39.10 \%$, respectively; L. Custódio, unpublished data). In the present study, a greater proportion of the variation was explained by the taxa, species or genera than by the conditions of the area of occurrence. Among the sympatric Qualea species, the seed abortion rate was higher in Q. parviflora, regardless of the area. Hence, in the species studied, seed abortion is probably linked to morphological and physiological characteristics of the plants, which drive ovule ontogeny and resource allocation (Wiens 1984; Bawa et al. 1989; Uma-Shaanker \& Ganeshaiah 1997).

However, some variation between populations/areas did occur in Callisthene fasciculata and Qualea parviflora. Studies of other species have reported differences among populations in terms of the seed abortion rate, attributing those differences to the size and complexity of the populations, as well as to the quality of their environments (Nilsson \& Wästljung 1987; García et al. 2000; Raimundéz-Urrutia 2008). The results of those studies suggest that such differences result in pollination limitation and disturbance, especially in self-incompatible species such as C. fasciculata 
Pre-dispersal seed predation and abortion in species of Callisthene and Qualea (Vochysiaceae) in a Neotropical savanna
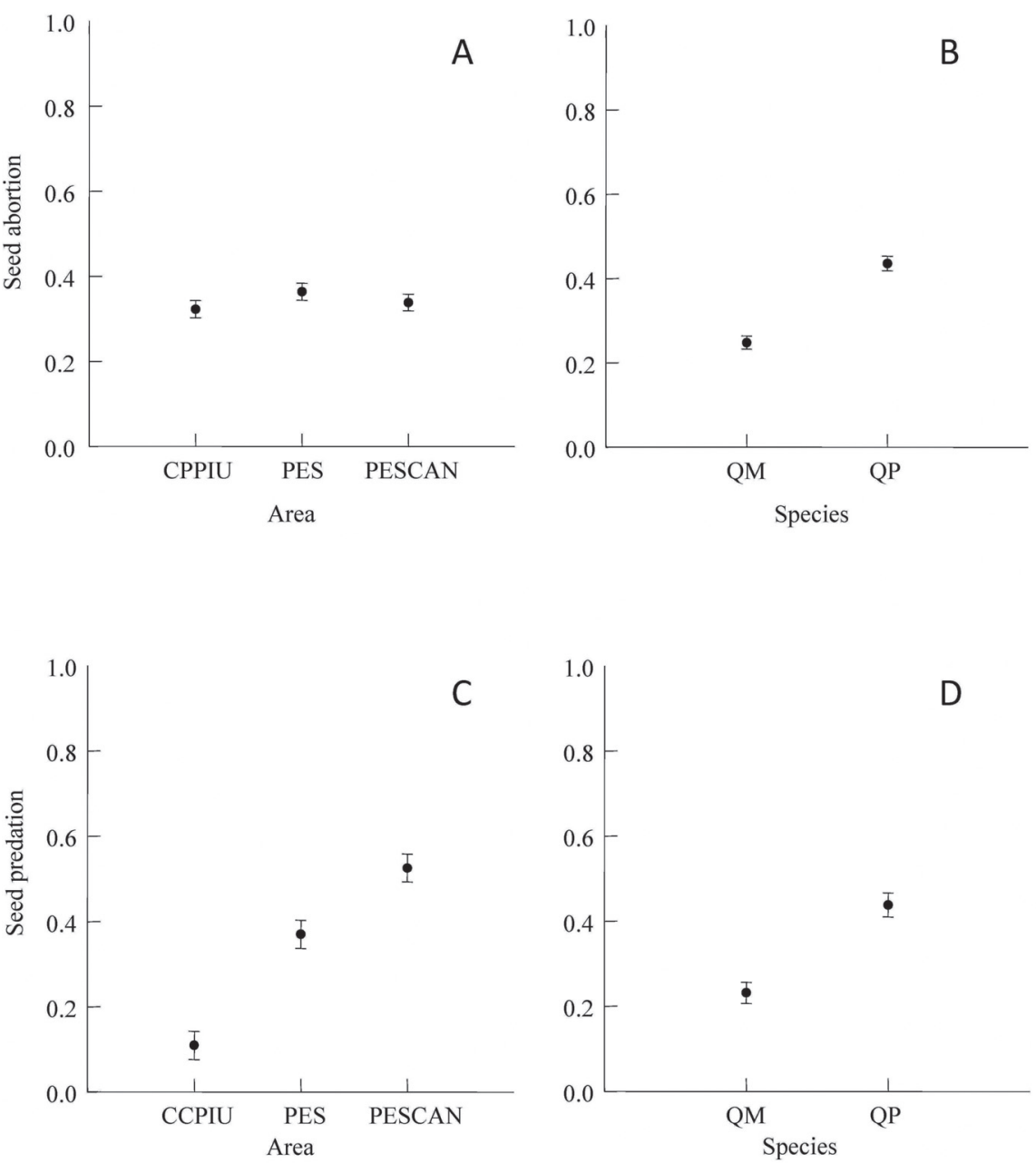

Figure 4. Rates of seed abortion and pre-dispersal seed predation for sympatric populations of Qualea multiflora (QM) and Qualea parviflora (QP). A and B. Seed abortion: A) no differences among areas (Wald's chi-square statistics $\left.\left.\left[\chi^{2}\right]=2.17 ; p=0.339\right) ; \mathbf{B}\right)$ significant differences between species $\left(\chi^{2}=72.60 ; p<0.001\right)$. C and $\mathbf{D}$. Seed predation: $\mathbf{C})$ significant differences among areas $\left.\left(\chi^{2}=5070.76 ; p<0.01\right) ; \mathbf{D}\right)$ significant differences between species $\left(\chi^{2}=5607.21 ; p<0.01\right)$.

Results are expressed as mean and standard error.

CCPIU - Clube Caça e Pesca Itororó de Uberlândia (Itororó Hunting and Fishing Club of Uberlândia); PES - Panga Ecological Station; PESCAN - Parque Estadual da Serra de Caldas Novas (Serra de Caldas Novas State Park).

Table 5. Correlations between the number of viable seeds and the predation rate in Qualea species, by area.

\begin{tabular}{|c|c|c|c|c|c|c|}
\hline \multirow[t]{2}{*}{ Species } & \multirow[t]{2}{*}{ Area } & \multirow[t]{2}{*}{$\mathrm{n}$ of fruits } & $\begin{array}{l}\text { Viable seeds per } \\
\text { fruit }\end{array}$ & $\begin{array}{l}\text { Insect-damaged } \\
\text { seeds per fruit }\end{array}$ & \multirow[t]{2}{*}{$r_{\mathrm{s}}$} & \multirow[t]{2}{*}{$p$} \\
\hline & & & $($ mean $\pm S D)$ & $($ mean $\pm S D)$ & & \\
\hline \multirow{4}{*}{ Qualea multiflora } & CCPIU & 62 & $4.661 \pm 1.039$ & $0.000 \pm 0.000$ & 0.000 & $>0.05$ \\
\hline & CBII & 50 & $4.480 \pm 1.129$ & $0.080 \pm 0.274$ & 0.373 & $<0.05$ \\
\hline & PES & 55 & $4.418 \pm 1.272$ & $1.018 \pm 1.557$ & 0.053 & $>0.05$ \\
\hline & PESCAN & 60 & $4.283 \pm 1.209$ & $1.883 \pm 1.678$ & 0.122 & $>0.05$ \\
\hline \multirow{4}{*}{ Qualea parviflora } & CCPIU & 43 & $3.372 \pm 1.273$ & $0.674 \pm 1.128$ & 0.034 & $>0.05$ \\
\hline & LF & 48 & $4.125 \pm 1.003$ & $2.083 \pm 1.622$ & 0.318 & $<0.05$ \\
\hline & PES & 47 & $3.106 \pm 1.127$ & $1.617 \pm 1.278$ & 0.638 & $<0.05$ \\
\hline & PESCAN & 49 & $3.592 \pm 1.513$ & $2.163 \pm 1.712$ & 0.537 & $<0.05$ \\
\hline
\end{tabular}

$r_{\mathrm{s}}$ - Spearman's correlation coefficient; CCPIU - Clube Caça e Pesca Itororó de Uberlândia (Itororó Hunting and Fishing Club of Uberlândia); CBII - natural areas surrounding the Capim Branco II hydroelectric dam; PES - Panga Ecological Station; PESCAN - Parque Estadual da Serra de Caldas Novas (Serra de Caldas Novas State Park); LF - Limoeiro farm. 
Luciana Nascimento Custódio, Renata Carmo-Oliveira, Clesnan Mendes-Rodrigues and Paulo Eugênio Oliveira

Table 6. Seed loss due to abortion and predation, together with final seed production, in the Vochysiaceae species studied.

\begin{tabular}{|c|c|c|c|c|}
\hline \multirow{2}{*}{ Species } & \multirow{2}{*}{ Area } & Seed abortion & Seed predation & Seed/ovule \\
\hline & & $(\%)$ & $(\%)$ & (\%) \\
\hline \multirow{2}{*}{ Callisthene fasciculata } & CBII & 68.24 & 0.00 & 31.76 \\
\hline & $\mathrm{LF}$ & 43.82 & 0.00 & 56.18 \\
\hline \multirow{2}{*}{ Callisthene major } & GEF & 53.20 & 0.00 & 46.80 \\
\hline & PARNASC & 56.82 & 51.34 & 18.27 \\
\hline \multirow{4}{*}{ Qualea multiflora } & CBII & 25.34 & 1.74 & 73.40 \\
\hline & CCPIU & 22.31 & 0.00 & 77.68 \\
\hline & PES & 24.54 & 23.05 & 56.67 \\
\hline & PESCAN & 27.51 & 43.97 & 40.00 \\
\hline \multirow{4}{*}{ Qualea parviflora } & CCPIU & 42.24 & 20.00 & 44.96 \\
\hline & $\mathrm{LF}$ & 31.25 & 50.51 & 34.03 \\
\hline & PES & 48.22 & 52.05 & 24.82 \\
\hline & PESCAN & 40.13 & 60.23 & 23.81 \\
\hline
\end{tabular}

CBII - natural areas surrounding the Capim Branco II hydroelectric dam; LF - Limoeiro farm; GEF - Glória Experimental Farm; PARNASC - Parque Nacional da Serra da Canastra (Serra da Canastra National Park); CCPIU - Clube Caça e Pesca Itororó de Uberlândia (Itororó Hunting and Fishing Club of Uberlândia); PES - Panga Ecological Station; PESCAN - Parque Estadual da Serra de Caldas Novas (Serra de Caldas Novas State Park).

and Q. parviflora.

\section{Pre-dispersal seed predation}

There was a clear distinction between the main insect groups found inside fruits and seeds of the Callisthene and Qualea species studied. The Curculionidae beetles found in fruits of $C$. major represent the largest family of beetles (Coleoptera), with 62,000 species (McKenna et al. 2009). These beetles are common seed predators of native plants, especially palms and legumes (Spironello et al. 2004; AlvesCosta \& Knogge 2005; Silva et al. 2007), as well as cultivated plants (Vilarinho 2007; Cícero 2007).

Most seed predators of Qualea multiflora and Q. parviflora were immature or adult Buprestidae beetles (Coleoptera) and micro-Hymenoptera. The Buprestidae also constitute a large group of Coleoptera, with some 15,000 species (Bellamy \& Nelson 2002). Although the major Buprestidae species are wood-borers, some are seed predators (Carslon \& Holsinger 2010). Insect damage to seeds and embryos usually prevents them from developing and germinating (Bradford \& Smith 1977; Zhang et al. 1997; Mickeliunas et al. 2006; Ribeiro et al. 2007).

The seed predation rate varied among the species studied, from null in Callisthene fasciculata to relatively high in Qualea parviflora and C. major (60.23 and 51.34\%, respectively). For Q. multiflora, pre-dispersal seed predation showed marked population-specific differences in seed predation rates ranging from null to $43.97 \%$. It is of note that seed predation was greatest in areas such as the PARNASC and PESCAN, which are larger and more well-preserved. Conservation status and area size can influence seed predators, because species richness and disturbance can affect those specialized interactions (Janzen 1975; Ehrlén 1996; Pizo 1997; García et al. 2000; Baldissera \& Ganade 2005).

\section{Relationship between seed abortion and predation}

Janzen (1971b; 1978) suggested that mother plants increase fruit and seed production as a strategy to satiate predators and guarantee a reliable seed supply, thereby ensuring germination and consequently recruitment. This satiation strategy is corroborated by various studies (Bradford \& Smith 1977; Ehrlén 1996; Steffan-Dewenter et al. 2001; Raimundéz-Urrutia 2008), which have shown that, although predation intensity increases in parallel with seed availability, there are always some seeds that escape predation. There is another possible strategy that would involve selective abortion of fruits and seeds as a way to deter predation (Ghazoul \& Satake 2009): seed and fruit abortion during development might be a strategy not only to adjust fruit and seed set to the physiological constraints of the mother plant but also to eliminate ovaries that had been preyed upon or parasitized. For the Qualea species studied here, there was a positive correlation between predation and the production of viable seeds. This might support the satiation hypothesis, although predation and seed production might both be linked simply to the better pollination observed at the sites that were larger and more well-preserved.

Our data on the Callisthene species studied here might support the idea that seed abortion acts as a counter strategy against predation, because those species showed high abortion rates and (mostly) low predation rates. It is conceivable that, if oviposition occurs early during fruit development, as it does in some Legume species (Janzen 1971a), abor- 
tion would eliminate many of the ovules in which insects had oviposited, thus reducing the seed predation rate. To a certain extent, the same reasoning could be used for the two Qualea species studied here.

In general, the species studied are under pressure from a variety of factors, which limits their reproductive success. As self-incompatible species, they present relatively low rates of conversion from flowers to fruits under natural conditions (Santos 1997; Oliveira 1998), and we found that many of their fruits presented seed abortion. In addition, we found that some of their seeds did not fully develop, because of pre-dispersal predation. We would expect seed production to be a bottleneck in the reproductive process. Nevertheless, despite losses to abortion and pre-dispersal predation, seed production in the species studied was similar to that reported for other, phylogenetically unrelated, species in the Cerrado Biome (e.g. Oliveira \& Silva 1993; Raimúndez-Urrutia 2008).

\section{Acknowledgments}

We thank the managers of the sampled areas for allowing us to collect fruits and seeds for this study. We are also grateful to Kleber del Claro, Larissa Nahas Domingues and Denise Lange, for their assistance in identifying the predatory insects; to Diana Salles Sampaio, for the comments and suggestions that helped us organize the data and text; and to the two anonymous reviewers, who suggested different approaches, which improved the manuscript. The study was funded by the Fundação de Amparo à Pesquisa do Estado de Minas Gerais (FAPEMIG, Research Grant no. CRA 2127/09) and by the Brazilian Coordenação de Aperfeiçoamento de Pessoal de Nível Superior (CAPES, Master's scholarship to LNC).

\section{References}

Allphin, L; Wiens, D. \& Harpert, K.T. 2002. The relative effects of resources and genetics on reproductive success in the rare kachina daisy. Erigeron Kachinensis (Asteraceae). International Journal of Plant Sciences 163(4): 599-612.

Almeida, A.F. \& Sarmento, F.N.M. (Coord.) 1998. Parque Estadual da Serra de Caldas - Plano de Manejo. Goiânia, CTE (Centro Tecnológico de Engenharia Ltda), FEMAGO - Fundação Estadual do Meio Ambiente GO.

Alves-Costa, C.P. \& Knogge, C. 2005. Larval concorrência gorgulhos Revena rubiginosa (Coleoptera: Curculionidae) alimentando-se de sementes da palmeira Syagrus romanzoffiana (Arecaceae). Naturwissenschaften 92(6): 265-268.

Andersen, A.N. 1988. Insect seed predators may cause far greater losses than they appear to. Oikos 52: 337-340.

Appolinário, V. \& Schiavini, I. 2002. Levantamento fitossociológico de espécies arbóreas de cerrado (stricto sensu) em Uberlândia - Minas Gerais. Boletim do Herbário Ezechias Paulo Heringer 10: 57-75.

Baldissera, R. \& Ganade, G. 2005. Predação de sementes ao longo de uma borda de floresta ombrófila mista e pastagem. Acta Botanica Brasilica 19(1): 161-165.

Barreto, M.R.; Anjos, N. \& Della Lucia, T.M. C. 1999. Comportamento Reprodutivo de Spermologus rufus Boheman (Coleoptera: Curculionidae). Anais da Sociedade Entomológica do Brasil 28(2): 351-354.
Bawa, K.S.; Hedge. S.G.; Ganeshaiah, K.N. \& Uma-Shaanker, R. 1989. Embryo and seed abortion in plants. Nature 342: 625.

Bellamy, C.L. \& Nelson, G.H. 2002: Buprestidae. Pp. 98-112. In: Arnett, R.H. Jr. \& Thomas, M.C. (Eds.). American Beetles (Volume 2). Boca Raton, CRC Press.

Boesewinkel, F.D. \& Venturelli, M. 1987. Ovule and seed structure in Vochysiaceae. Botanische Jahrbücher für Systematik 108: 547-566.

Bradford, D.F. \& Smith, C.C. 1977. Seed predation and seed number in Scheelea palm fruits. Ecology 58(3): 667-673.

Cardoso, E.; Moreno, M.I.C.; Bruna, E.M. \& Vasconcelos, H.L. 2009 Mudanças fitofisionômicas no cerrado: 18 anos de sucessão ecológica na Estação Ecológica do Panga. Uberlândia - MG. Caminhos de Geografia Uberlândia 10: 254-268.

Carmo-Oliveira, R. 1998. Estudos embriológicos e aspectos da morfologia floral de Vochysiaceae. Tese de Doutorado. São Paulo, Universidade de São Paulo.

Carlson, J.E. \& Holsinger, K.E. 2010. Natural selection on inflorescence color polymorphisms in wild Protea populations: the role of pollinators, seed predators, and intertrait correlations. American Journal of Botany 97: 934-944.

Chacoff, N.P.; Garcia, D. \& Obeso, J.R. 2008. Effects of pollen quality and quantity on pollen limitation in Crataegus monogyna (Rosaceae) in NW Spain. Flora 203: 499-507.

Crawley, M.J. 2007. The R Book. Chichester, John Wiley and Sons, Ltd.

Cícero, E.A.S. 2007. Caracterização molecular e seleção de isolados de Bacillus thuringiensis com potencial inseticida para Sphenophorus levis. Tese de Doutorado. Faculdade de Ciências Agrárias e Veterinárias. Jaboticabal, Universidade Estadual Paulista - Unesp.

Crawley, M.J. 2000. Seed predators and plant population dynamics. Pp. 167-182. In: Fenner, M. (Ed.). Seeds: the ecology of regeneration in plant communities. Wallingford. CABI Publishing.

Dhar, R.; Sharma, N. \& Sharma, B. 2006. Ovule abortion in relation to breeding system in four Trifolium species. Current Science 91(4): 482-485.

Ehrlén, J. 1996. Spatiotemporal variation in predispersal seed predation intensity. Oecologia 108 (4): 708-713

Farnsworth, E. 2000. The ecology and physiology of viviparous and recalcitrant seeds. Annual Review of Ecology and Systematics 31: 107-138.

Figueiredo, P.S.; Girnos, E.C. \& Santos, L.S. 2008. Predação e parasitismo em sementes de duas populações de Parkia platycephala Benth. em áreas de cerrado no nordeste do Brasil. Revista Brasileira de Botânica 31(2): 245-251.

García, D.; Zamora, R.; Gómez, J.M.; Jordano, P. \& Hódar, J.A. 2000. Geographical variation in seed production. predation and abortion in Juniperus communis throughout its range in Europe. Journal of Ecology 88: 436-446.

García, D.; Zamora, R.; Gómez, J.M. \& Hódar, J.A. 2001. Frugivory at Juniperus communis depends more on population characteristics than on individual attributes. Journal of Ecology 89: 639-647

Ghazoul, J. \& Satake, A. 2009. Non-viable seed set enhances plant fitness: the sacrificial sibling hypothesis. Ecology 90(2): 369-37.

Gribel, R. \& Gibbs, P.E. 2002. High outbreeding as a consequence of selfed ovule mortality and single vector bat pollination in the Amazonian tree Pseudobombax munguba (Bombacaceae). International Journal of Plant Sciences 163(6): 1035-1043.

Haig, D. \& Westoby, M. 1988. Inclusive fitness, seed resources, and maternal care. Pp. 60-79. In: Doust, J.L. \& Doust, L.L. (Eds.) Plant reproductive ecology: patterns and strategies. New York, Oxford University Press.

Haridasan, M. \& Araújo, G. M. 1988. Aluminium-accumulating species in two Forest communities in the cerrado region of Central Brazil. Forest Ecology and Management 24: 15-26.

Janzen, D.H. 1970. Herbivores and the number of tree species in tropical forests. American Naturalist 104: 501-528.

Janzen, D.H. 1971a. Escape of Cassia grandis L. beans from predators in time and space. Ecology 52(6): 964-979.

Janzen, D.H. 1971b. Seed predation by animals. Annual Review of Ecology, Evolution, and Systematics 2: 465-92.

Janzen, D.H. 1975. Intra- and interhabitat variations in Guazuma ulmifolia (Sterculiaceae) seed predation by Amblycerus cistelinus (Bruchidae) in Costa Rica. Ecology 56: 1009-1013. 
Janzen, D.H. 1978. Seeding patterns of tropical trees. Pp. 83-128. In: Tomlinson, P.B. \& Zimmermmann, M.H. (Eds.) Tropical trees as living systems. Cambridge, Cambridge University Press.

Kärkkäinen, K.; Savolainen, O. \& Koski, V. 1999. Why do plants abort so many developing seeds: bad offspring or bad maternal genotypes? Evolutionary Ecology 13: 305-317.

Latta, R.G. 2005. The effects of embryo competition with mixed mating on the genetic load in plants. Heredity 75: 637-643.

Leimu, R.; Syrjänen, K.; Ehrlén, J. \& Lehtilä, K. 2002. Pre-dispersal seed predation in Primula veris: among-population variation in damage intensity and selection on flower number. Oecologia 133: 510-516.

Lopes, S.F.; Vale, V.S.; Oliveira, A.P. \& Schiavini, I. 2011. Análise comparativa da estrutura e composição florística de Cerrado no Brasil Central. Interciencia 36(1): 8-15.

López-Almansa, J.C.; Yeung, E.C. \& Gil, L. 2004. Abortive seed development in Ulmus minor (Ulmaceae). Botanical Journal of the Linnean Society 145: $455-467$

Marino, P.C.; Westerman, P.R.; Pinkert, C. \& Van der Werf, W. 2005. Influence of seed density and aggregation on post-dispersal weed seed predation in cereal fields. Agriculture, Ecosystems \& Environment 106: 17-25.

Mattson, W.J.Jr. 1980. Herbivory in relation to plant nitrogen content. Annual Review of Ecology and Systematics 11: 119-161.

McKenna, D. D.; Sequeirab, A. S.; Marvaldic, A.E. \& Farrella, B.D. 2009. Temporal lags and overlap in the diversification of weevils and flowering plants. PNAS 106: 7083-7088.

Melser, C. \& Klinkhamer, P.G.L. 2001. Selective seed abortion increases offspring survival in Cynoglossum officinale (Boraginaceae). American Journal of Botany 88(6): 1033-1040.

Mickeliunas, L.; Pansarin E.R. \& Sazima. M. 2006. Biologia floral. melitofilia e influência de besouros Curculionidae no sucesso reprodutivo de Grobya amherstiae Lindl. (Orchidaceae: Cyrtopodiinae). Revista Brasileira de Botânica 29: 251-258

Nilsson, S.G. \& Wästljung, U. 1987. Seed predation and cross-pollination in mast-seeding Beech (Fagus Sylvatica) patches. Ecology 68: 260-265.

Oliveira, P.E. \& Silva, J.C.S. 1993. Reproductive Biology of Two Species of Kielmeyera (Guttiferae) in the Cerrados of Central Brazil. Journal of Tropical Ecology 9: 67-79.

Oliveira, P.E. 1998. Reproductive biology, evolution and taxonomy of the Vochysiaceae in Central Brazil. Pp. 381-393. In: Owens, S. \& Ruddal, P. (Eds.) Reproductive Biology: in systematics, conservation and economic botany. Richmond. Royal Botanic Gardens at Kew.

Palser, B.F.; Rouse, J.L. \& Willians, E.G. 1990. Aberrant ovules and megagametophytes in Rhododendron nuttallii (Ericaceae). Botanical Gazette 151(1): 73-87.

Pizo, M.A. 1997. Seed dispersal and predation in two populations of Cabralea canjerana (Meliaceae) in the Atlantic forest of Southeastern Brazil. Journal of Tropical Ecology 13(4): 559-577.

Porcher, E. \& Lande, R. 2005. Reproductive compensation in the evolution of plant mating systems. New Phytologist 166: 673-684.

Ratter, J.A.; Bridgewater, S.; Atkinson, R. \& Ribeiro, J.F. 1996. Analysis of the floristic composition of the Brazilian Cerrado vegetation II: comparison of the woody vegetation of 98 areas. Edinburgh Journal of Botany 53: 153-180.

Raimúndez-Urrutia, E. 2008. Abortion and pre-dispersal seed predation in the American Proteaceae Roupala montana Aubl. Caribbean Journal of Science 44: 164-174.

Ribeiro, M.L.; Sales, V.A.; Miranda, F.S.; Soares, C.E.A. \& Oliveira, A.C.C. 2007. Influência da predação de sementes na germinação de leguminosas (Fabaceae) no Cerrado. Revista Brasileira de Biociências 5(2): 279-281.
Romero, R. \& Nakajima, J.N. 1999. Espécies endêmicas do Parque Nacional da Serra da Canastra. Minas Gerais. Revista Brasileira de Botânica 22: 259-265.

Santos, M.L. 1997. Biologia de polinização e reprodução de Callisthene fasciculata e Qualea parviflora em cerrado sobre afloramento basáltico, Araguari-MG. Dissertação de Mestrado. Brasília, Universidade de Brasília.

Schiavini, I. \& Araújo, G.M. 1989. Considerações sobre a vegetação da Reserva Ecológica do Panga (Uberlândia). Sociedade \& Natureza 1(1): 61-66.

Sedgley, M. \& Granger, L. 1996. Embryology of Eucalyptus spathulata and E. platypus (Myrtaceae) following selfing, crossing and reciprocal interspecific pollination. Australian Journal of Botany 44: 661-671.

Silva, F.R. da; Begnini, R.M.; Scherer, K.Z.; Lopes, B.C. \& Castellani, T.T 2007. Predação de sementes de Syagrus romanzoffiana (Cham.) Glassman (Arecaceae) por insetos na Ilha de Santa Catarina. SC. Revista Brasileira de Biociências 5(supl. 1): 681-683.

Sorensen, F.C. 1982. The roles of polyembryony and embryo viability in the genetic system of Conifers. Evolution 36(4): 725-733.

Spironello, W.R.; Sampaio, P. de T.B. \& Ronchi-Teles, B. 2004. Produção e predação de frutos em Aniba rosaeodora Ducke var. amazonica Ducke (Lauraceae) em sistema de plantio sob floresta de terra firme na Amazônia Central. Acta Botanica Brasilica 18 (4): 801-907.

Steffan-Dewenter, I.; Münzenberg, U. \& Tscharntke, T. 2001. Pollination, seed set and seed predation on a landscape scale. Proceedings of The Royal Society 268: 1685-1690

Stephenson, A.G. 1981. Flower and fruit abortion: proximate causes and ultimate functions. Annual Review of Ecology and Systematics 12 253-279.

Teixeira, S. de P.; Pereira, R.A.S. \& Ranga, N.T. 2006. Components of Fecundity and Abortion in a Tropical Tree, Dahlstedtia pentaphylla (Leguminosae). Brazilian Archives of Biology and Technology 49: 905-913.

Tuda, M.; Wu, L.; Tateishi, Y.; Niyomdham, C.; Buranapanichpan, S.; Morimoto, K.; Wu, W.; Wang, C.; Chen, Z.; Zhu, H.; Zhang, Y.; Murugan, K.; Chou, L. \& Johnson, C.D. 2009. A novel host shift and invaded range of a seed predator, Acanthoscelides macrophthalmus (Coleoptera: Chrysomelidae: Bruchinae), of an invasive weed, Leucaena leucocephala. The Entomological Society of Japan 12: 1-8.

Uma-Shaanker, R. \& Ganeshaiah, K.N. 1997. Conflict between parent and offspring in plants: predictions, processes and evolutionary consequences. Current Science 72(12): 932-939.

Vilarinho, K.R. 2007. Análise da variabilidade genética de populações de Anthonomus grandis (Coleoptera: Curculionidae), na cultura do algodoeiro. Dissertação de Mestrado. Faculdade de Agronomia e Medicina Veterinária, Brasília, Universidade de Brasília.

Ward, M.; Dick, C.W.; Gribel, R. \& Lowe, A.J. 2005. To self, or not to self... A review of outcrossing and pollen-mediated gene flow in Neotropical trees. Heredity 95: 246-254

Wiens, D. 1984. Ovule survivorship, brood size, life history, breeding systems, and reproductive success in plants. Oecologia 64: 47-53.

Wiens, D.; Calvin, C.L.; Wilson, C.A.; Davern, C.I.; Frank, D. \& Seavey, S.R. 1987. Reproductive success, spontaneous embryo abortion, and genetic load in flowering plants. Oecologia 71: 501-509.

Willson, M. F. 1983. Plant reproductive ecology. New York, John Wiley \& Sons.

Zhang, J.; Drummond, F.A.; Liebman, M. \& Hartke, A. 1997. Insect Predation of Seeds and Plant Population Dynamics. Maine Agricultural and Forest Experiment Station Technical Bulletin 163: 32. 